\title{
УКРАЇНСЬКА РЕДАКЦІЯ РАДІО «СВОБОДА»: ПРОТИДІЯ РОСІЙСЬКИМ ІНФОРМАЦІЙНИМ ФЕЙКАМ
}

\author{
Іван Ципердюк \\ ПВНЗ «Університет Короля Данила», \\ вул. С. Коновальия, 35, 76000, Івано-Франківськ, Україна \\ e-mail: ivandjuk@ukr.net \\ https://orcid.org/0000-0003-0940-5066
}

У статті проаналізовано, як українська редакція радіо «Свобода» протистоїть поширенню російських інформаційних фейків та інформує аудиторію про їх викриття. Розглянуто досвід редакції у підготовці матеріалів, де роз'яснюється, як розпізнати фейки. Відзначено, що українська редакція радіо «Свобода» в роботі дотримується високих професійних стандартів, уникаючи новин з ознаками недостовірності. Наголошено, що в час російської військової агресії проти України особливу вагу має протидія інформаційним атакам, які їі супроводжують, зокрема у вигляді поширення фейків.

Ключові слова: українська редакція радіо «Свобода», фейки, пропаганда, інформаційна війна.

Упродовж «холодної війни» одним із головних завдань української редакції радіо «Свобода» було викриття дезінформації, що іiї масово продукувала радянська пропаганда. Комуністична ідеологія, якою керувалися ЗМІ СРСР, спонукала їх свідомо перекручувати та спотворювати факти, підтасовуючи їх для творення ілюзії справедливості та добробуту, що начебто панують у радянському суспільстві.

Єдиним способом ефективно протистояти державній машині з виготовлення дезінформації було поширення правди. І цю роботу впродовж багатьох десятиліть і3-посеред багатьох інших радіостанцій, які вели мовлення на Радянський Союз, виконувала українська редакція радіо «Свобода». Вона не лише інформувала про реальний стан справ у країні «розвинутого соціалізму», але й стала голосом переслідуваної опозиції - численних українських дисидентів, які намагалися протистояти тоталітарній державі.

Натомість у СРСР цілеспрямовано проводили пропагандистську кампанію, спрямовану на дискредитацію «ворожих радіоголосів», і постійно намагалися довести, що західні радіостанції подають неправдиві новини. Це врешті мало для Радянського Союзу та державних ЗМІ фатальні наслідки. Офіційній пропаганді не вірили не лише звичайні громадяни, але й самі представники радянських мас-медіа, завданням яких було продукувати «правильні» матеріали. Про це пише Д. Саттер: «Коли журналісти ТАРС (Телеграфне агентство Радянського Союзу. - I. Ц.) вранці

(C) Ципердюк I., 2019 
приходили на роботу, вони зазвичай обговорювали те, що чули напередодні ввечері від західних радіостанцій, вважаючи їх цілком надійними джерелами інформації. Проте вони ніколи не обговорювали змісту радянської преси, включно з власними кореспонденціями, які через замовчування вважали нічого не вартими» [1, с. 85].

Сучасні російські ЗМІ успадкували весь арсенал засобів, притаманних радянській пропаганді. Російські медіа лише адаптували їх до сучасних інформаційних та технічних реалій. «Радіовійна», яка тривала між СРСР та Заходом у ХХ ст., зараз перетворилася в інформаційну війну, яку Росія веде проти України, разом з військовою агресією: «Різниця між російською і радянською пропагандою в тому, що російська не намагається представити Росію в кращому світлі для решти світу, як це робив СРСР. Їм все одно, що думають європейці про Росію. Мета російської пропаганди створювати політичні поділи всередині європейських країн» [2]. Відповідно більш витонченими стали засоби ведення російськими медіа інформаційної війни. Одним із ключових елементів таких дій, спрямованих на деморалізацію, поширення паніки та введення в оману населення держави, на яку скерована інформаційна атака, $є$ масове поширення фейків.

Необхідно відзначити, що українські науковці, незважаючи на кількарічну військово-інформаційну агресію Росії щодо України, лише фрагментарно звертали свою увагу на цю гостру проблему. Основним дослідником технології створення фейків і їхнього впливу на населення $є$ професор Г. Почепцов, який підготував низку статей, присвячених цій проблематиці. Видавничий дім «Києво-Могилянська академія» вже анонсував публікацію окремої книги Г. Почепцова «Фейк. Технології спотворення реальності», у якій досліджується, як створюються фейки, чому вони так легко поширюються і якими є ефективні методи боротьби з ними. Вартим уваги $\epsilon$ також статті М. Кіци та I. Мудрої, присвячені впливу фейкової інформації в українських соціальних медіа на аудиторію та видам фейків у ЗМІ. Основні зусилля у роз'ясненні як журналістам, так і громадськості, що ж таке фейки, яку вони несуть загрозу і як їх розпізнавати, взяли на себе спеціалізовані інтернет-портали: StratComUA, InformNapalm, OSINT Academy та ін., найавторитетнішим із яких у цьому напрямку є StopFake (https://www.stopfake.org/uk/golovna/). Низка українських ЗМІ та закордонних, які представлені в Україні, також веде послідовну роботу з виявлення та викриття російських фейків. Одним із них є українська редакція радіо «Свобода».

Мета нашого дослідження - проаналізувати, як українська редакція радіо «Свобода» сприяє виявленню російських інформаційних фейків, повідомляє про них громадськість, запобігає їхньому поширенню.

Лише 2018 року російські ЗМІ поширили в інформаційному просторі одну тисячу фейків, у яких значно частіше за інші країни (461 раз) ішлося про Україну. Це зафіксовано в підсумковому звіті організації « $\mathrm{EC}$ проти дезінформації» («EU vs Disinformation») [3]. Ці дані підтверджують, що Україна продовжує бути основним об’єктом інформаційної війни (разом з військовою агресією) з боку Росії. Масове поширення фейків $є$ одним із дешевих та ефективних способів спотворення фактів і введення в оману населення країни, на яку спрямована інформаційна атака.

Що ж таке фейк? Основне значення терміна «фейк» (англ. fake) - 'підробка'. Фахівці Інституту масової інформації (IMI) роз'яснюють, як у зв'язку з інтенсивним розвитком медіа-сфери та активного ведення інформаційних війн цей термін набув 
нового значення: «Це слово спершу застосовували як назву для підробок під відомі бренди. Пізніше, з поширенням соціальних мереж, його почали застосовувати як означення несправжніх акаунтів, а 3 початком активної фази інформаційної війни це поняття все ширше почали використовувати для назви неправдивої інформації або неправдивих фото/відео до такої інформації. Інформаційна агресія призвела до появи тисячі людей, для яких стало вигідно поширювати фейкову інформацію, а для деяких це стало роботою. Тому це поняття стало реальним викликом для українських журналістів» [4]. Варто також наголосити, що фейк не є синонімом вислову «неправдива інформація». Неправдива інформація подекуди є наслідком байдужості журналістів, які не перевіряють отриманих відомостей. Натомість «фейк»- це цілком свідоме, умисне перекручення та спотворення фактів 3 метою дезінформування аудиторії. Тому погоджуємось із твердженням, що «фейк» $є$ «видом неправдивої інформації, а не її ототожненням» [5, с. 283].

Росія не єдина країна, яка масово поширює фейки, але вона займається цією руйнівною діяльністю найефективніше: «вона, напевно, є одним із найбільш впливових та успішних противників у сучасній інформаційній війні. Причому ця війна дорого не коштує, і Росія, яка має набагато менші економічні можливості, може мати «дешевший» вплив, завдяки маніпуляціям у соціальних мережах. Згідно 3 дослідженнями американської мережі Twitter, фейкові повідомлення поширюються мережею у шість разів швидше, ніж правдиві» [6].

Українська редакція радіо «Свобода» проводить системну роботу щодо інформування аудиторії про викриття чергових фейків російських пропагандистських ЗМІ та поширення фейків російськими тролями в соціальних мережах. Журналісти редакції поруч із колегами з інших українських медіа, активістами з громадських ініціатив послідовно займаються виявленням чергових російських інформаційних фейків. Підтвердженням цього є перше місце, яке посіла журналістка української редакції радіо «Свобода» Свгенія Тюхтенко 2018 року на конкурсі «Лови фейк», що його проводив IMI в межах проекту «Розвиток відповідальних інтернет-3МI». Одним із основних завдань конкурсу було виявлення російських інформаційних фейків. Нагородою відзначено фотофейк із українським солдатом, що повертався 3 Донбасу. Він став найкращим у номінації «Виявлення фейкових зображень у медіа». Є. Тюхтенко знайшла військового, зображеного на фотографії, і він спростував фейкову інформацію, яка супроводжувала цю світлину, що їі масово поширювали в мас-медіа та соціальних мережах. Підпис, що супроводжував це фото, був такого змісту: «Боєць АТО проводжає свою дівчину в Москву». Солдат розповів, що насправді він повертався із зони бойових дій до Тернополя і на вокзалі його зустріла дівчина [7].

Українська редакція радіо «Свобода» також розміщує матеріали та інтерв`ю, у яких роз'яснюється, що таке фейки, як їх розпізнавати та викривати. Російські пропагандисти навчилась уміло маскувати фейки, видаючи їх за правдиву інформацію. Із цього приводу головний редактор інтернет-видання «Тексти», яке бореться з фейками, Р. Кульчинський в інтерв’ю спецпроекту української редакції радіо «Свобода» «Донбас. Реалії» зауважив: «Зіштовхнулися з проблемою, що ніхто не знає, що таке «фейкові» новини, немає визначення. Чисті «фейки», як, наприклад, «розіп'ятий хлопчик», бувають дуже рідко. Але є інші типи, як правило, це маніпуляція: є реальна подія, але робляться неправильні висновки або дещо перекручуються» [8]. 
Наскільки серйозною та гострою є ця проблема, свідчить той факт, що дослідження, яке провели медіа-експерти «Текстів» упродовж грудня 2017 - жовтня 2018 року засвідчило, що поширенням маніпуляцій займаються 80 сайтів - українських або таких, що спеціалізуються на українській тематиці; журналісти їх ще називають «зливними бачками» [9]. Головний редактор «Громадського радіо» К. Лукеренко в ефірі «Донбас. Реалії» наголошує: «Фейки можуть бути небезпечними, тому що вони штовхають нас до прийняття рішень, які ми б не прийняли, якби нас не обдурили. Вони нас залякують і приводять до якихось дій, які ми б не зробили, маючи більш якісну картину» [10]. Український політтехнолог Д. Богуш, оцінюючи масштаби російської інформаційної «фабрики фейків», в інтерв’ю українській редакції радіо «Свобода» в грудні 2018 року наводить такі дані: «Протягом дня тільки на одному сайті, наприклад «РИА-Новости», це може будь-хто перевірити, з'являється близько 700 новин на день, з яких десь 150 - про Україну» [6]. Значна частина 3 них, зауважує політтехнолог, є фейковими.

Атака фейкових повідомлень незмінно супроводжує будь-яку чергову провокацію, яку Росія готує проти України. У минулорічному грудневому огляді іноземної преси українська редакція радіо «Свобода» наводить інформацію з британської газети «The Guardian». Видання розкривало механізм дезінформації, який Росія запустила за рік до подій у Керченській протоці, щоб виправдати свою пряму військову агресію щодо України перед європейцями: «Влітку цього року ЗМІ Росії поширили фейки, ніби Україна інфікувала Азовське море холерою, а восени у російських медіа з’явилися прогнози про «спровоковані Заходом заворушення в регіоні». Також були заяви про те, що США планували протистояння між Росією та Україною в Чорному морі ще 390 -х років. Інший фейк - британські та українські спецслужби намагалися транспортувати ядерну бомбу, щоб підірвати новозбудований Кримський міст, але їх зупинили російські спецслужби. Хоча усі ці заяви - неправда, вони мали серйозний вплив на громадську думку в СС, часто завдяки тому, що прокремлівські ресурси перші за пошуками в Google» [11].

Послідовна робота української редакції радіо «Свобода» щодо виявлення фейків, запобігання їхньому поширенню та ведення просвітницької діяльності в цій сфері була високо оцінена в дослідженні, яке спільно провели IMI та видання «Тексти» 2018 року. Згідно з його результатами сайт української редакції радіо «Свобода» увійшов до четвірки з 50 найбільш популярних в Україні сайтів, у новинах яких немає ознак недостовірності. Для оцінки було застосовано такі критерії: ненадійне джерело інформації, недостовірна новина, маніпулятивний заголовок, фейк, маніпуляції з емоціями та мова ворожнечі.

Прогнозовано на першому місці антирейтингу опинилася російська «Комсомольская правда», яка входить у топ-50 видань, які найбільше читають в Україні. Російський політолог С. Медведєв, що аналізує російські блоги, у коментарі для радіо «Свобода» заявив, що Росія закидає світ інформаційним сміттям та брехливими повідомленнями, а її пропаганда є частиною державної політики: «Росія стала чемпіоном зі створення дезінформації та маніпулятивних інформацій. Це не завжди неправдива інформація, не завжди вигадане повідомлення, але воно, приміром, не відповідає фото чи відео до нього. Це такий вид гібридної новини» [12].

У медіа-просторі триває справжня війна з російськими фейками, і українська редакція радіо «Свобода», діяльність якої побудована на дотриманні високих жур- 
налістських стандартів, усіма доступними засобами викриває маніпулятивну інформацію. На жаль, як наголошує викладач курсу «Політичні комунікації» в Школі журналістики Українського католицького університету С. Ланюк, «сьогодні люди часто моделюють свої уявлення про російсько-українську війну, грунтуючись на досвіді Другої світової, але ми живемо в іншу епоху. Ми живемо в епоху соціальних мереж, в епоху, коли інформація активно використовується як зброя. I коли одна країна здатна дестабілізувати і впливати на політичний простір іншої країни, зокрема за допомогою інформації, інформаційні війни стають дуже важливими засобами ведення бойових дій і впливу на політичну ситуацію в інших країнах» [13].

Фейки якраз належать до арсеналу такої інформаційної зброї, яку інтенсивно використовує Росія. Соціологічне дослідження «Довіра до ЗМІ, вплив російської пропаганди, медіаграмотність в Україні», оприлюднене 2018 року, засвідчує, що 61\% українців не хоче брати участі в навчальних курсах з медіаграмотності, а 30\% відсотків опитаних визнали свою повну неспроможність відрізнити якісну інформацію від фейків. І це в ситуації, коли «інформаційний простір зараз насичений фейковими матеріалами, коментарями. Вони генеруються спеціально, щоб створювати інформаційний шум, спотворювати інформацію і не дати змоги читачеві докопатися до істини. Простір забивається різноманітними даними з певної події і читач просто губиться у них» [14].

Тому українська редакція радіо «Свобода» разом з багатьма іншими вітчизняними 3МІ та громадськими організаціями змушена не лише розвінчувати російські пропагандистські фейки, але й роз'яснювати аудиторії їхню небезпеку та способи їх виявлення.

Якщо ввести в пошукову систему сайту української редакції радіо «Свобода», термін «фейк», то відкриється понад півтисячі посилань: на матеріали, у яких викриваються російські інформаційні підробки, інтерв’ю з фахівцями, що пояснюють важливість цієї проблеми, повідомлення про виявлення чергової пропагандистської фальшивки. Напередодні президентських виборів 31 березня 2019 року варто вкотре очікувати масової атаки російських ЗМІ на Україну. Юрист бельгійської державної телерадіомовної компанії RTBF Стефан Обек, коментуючи ситуацію, що склалася у зв'язку з російським інформаційним впливом на вибори в різних країнах, наголошує: «Навіть якщо інформаційна сфера зовні виглядає чимось абстрактним та нематеріальним, шкоду, яку вона може нанести державам, можна порівняти із екологічною катастрофою. Візьміть вибори в деяких країнах: їх виграють особи з неочікуваними результатами, аналізи яких виявляють маніпуляції засобами масової інформації, згубний вплив соцмереж та фейків» [15].

Українська редакція радіо «Свобода» в одному з нещодавніх матеріалів [16] навела аналітику агентства для боротьби з російською пропагандою «EU vs Disinfo», яка засвідчує, що російські тролі 2018 року продовжували свою активну «роботу» 3 виготовлення фейків і дезінформації та нарощують обсяги виготовлення фальшивок 2019 року. Вони попереджають, що головною темою та основним об'єктом інформаційних маніпуляцій російської пропаганди залишається Україна, у якій упродовж року відбудеться аж троє виборів: Президента, Верховної Ради та органів місцевого самоврядування. Однак із російською дезінформацією та фейками можна ефективно боротися, якщо цю роботу проводити цілеспрямовано та послідовно. Це зокрема засвідчує діяльність української редакції радіо «Свобода». 
Із цього приводу журналістка видання «Детектор медіа» Г. Скляревська в інтерв’ю спецпроекту української редакції радіо «Свобода» «Донбас. Реалії» зауважує: «Незалежно від того, заперечуємо ми фейки чи іронізуємо, є ситуація маніпуляції інформаційним простором України просто за фактом вкидання. Ми починаємо це обговорювати, заперечувати, давати на цю тему інтерв’ю. Так чи інакше ця тема знову виникає в інформаційному полі України. У мене немає рецепту, як уникнути впливу Росії. Але було б непогано, якби всі українські медіа подавали інформацію зважено, збалансовано» [17]. Українська редакція радіо «Свобода» якраз належить до тих 3МІ, що послідовно дотримуються зваженої редакційної політики, з одного боку, розвінчуючи російські фейки, а з іншого - не занадто акцентуючи увагу на кожному з них, таким чином уникаючи мимовільної популяризації та поширення інформації про маніпулятивні повідомлення.

Дослідження протидії української редакції радіо «Свобода» російським інформаційним фейкам дає нам підстави зробити такі висновки.

Редакція володіє досвідом протидії тоталітарній пропаганді, яка активно використовувала спотворені інформаційні повідомлення, ще 3 часу «холодної війни». Вона постійно інформує аудиторію про викриття чергових російських інформаційних фальшивок. Журналісти редакції активно займаються виявленням фейків, постійно готують матеріали та інтерв'ю, у яких роз'яснюється, що таке фейки, як їх розпізнавати та викривати; лаконічністю, зваженим аналізом, точністю викладу запобігають їхній популяризації. Українська редакція радіо «Свобода» дотримується у власній роботі високих професійних стандартів, що дозволило іï сайту увійти до п’ятірки вітчизняних ресурсів, у новинах яких немає ознак недостовірності.

У час, коли триває російська військова агресія щодо України, протидія інформаційним атакам, які її супроводжують, є особливо важливою. Масове поширення фейків російськими ЗМІ та інтернет-тролями належить до арсеналу боротьби 3 колишніми радянськими республіками, а зараз незалежними державами, 3 метою їх повернення у статус російських колоній. Українська редакція радіо «Свобода», протидіючи російським фейкам, допомагає Українській державі вистояти в умовах інформаційної війни.

Вивчення багатолітнього досвіду протидії української редакції радіо «Свобода» радянській пропаганді, а згодом російській інформаційній агресії $є$ перспективною темою для дослідження, враховуючи його актуальність для нинішніх складних реалій, у яких перебуває Українська держава.

\section{REFERENCES}

1. Саттер Д. Доба безумства. Занепад і кінець Радянського Союзу / Девід Саттер ; пер. $з$ англ. Наталії Комарової. К. : ДУХ І ЛІТЕРА, 2017. 528 с.

2. Духніч О. Незручні відповіді. Зоряна журналістка Енн Епплбаум предметно пояснює, як і чому Росія прагне розвалити СС [Електронний ресурс] / О. Духніч. Режим доступу: https://magazine.nv.ua/ukr/journal/3153-journal-no-20/nezruchnividpovidi.html (дата звернення: 22.01.19).

3. Смирнов А. Москва метає фейки [Електронний ресурс] / А. Смирнов. - Режим доступу: https://nv.ua/ukr/opinion/moskva-metaje-fejki-2516576.html (дата звернення: 22.01.19). 
4. Голуб О. Фейки, журстандарти та спрощення картини світу [Електронний ресурс] / О. Голуб. - Режим доступу: https://imi.org.ua/articles/feyki-jurstandarti-tasproschennya-kartini-svitu/ (дата звернення: 22.01.19).

5. Кіца М. О. Фейкова інформація в українських соціальних медіа: поняття, види, вплив на аудиторію / М. О. Кіца // Наукові записки [Української академії друкарства]. 2016. № 1. С. 281-287. [Електронний ресурс]. - Режим доступу: http://nz.uad. lviv.ua/static/media/1-52/36.pdf (дата звернення: 22.01.19).

6. Кречко Я., Овіннікова Т. «Руїни, злидні, фашизм і терор»-як росіяни в прямому ефірі воюють з Україною [Електронний ресурс] / Я. Кречко, Т. Овіннікова. - Режим доступу: https://www.radiosvoboda.org/a/donbas-realii-yak-rosiyany-vpryamomu-efiri-voyuut-z-ukrainoyu/29659173.html

7. Журналістка перемогла на «Лови фейк» 3 матеріалом про бійця ЗСУ та «дівчину з Москви» [Електронний ресурс]. - Режим доступу: https://dn.depo.ua/ukr/ dn/zhurnalistka-peremogla-na-lovi-feyk-z-materialom-pro-biycya-zsu-ta-divchinu-zmoskvi-foto-20181024858595

8. Тимошенко Д. «Зливні бачки» і сайти, які поширюють російську пропаганду [Електронний ресурс] / Д. Тимошенко. - Режим доступу: https://www.radiosvoboda. org/a/donbas-realii/29628819.html

9. Медіа-експерти склали список новинних сайтів-«бачків» [Електронний ресурс]. - Режим доступу: https://ukr.lb.ua/news/2018/11/28/413608_mediaeksperti_ sklali_spisok.html

10. Бучельнікова М. Фейки толкают нас к принятию решений, которые мы бы не приняли без обмана - Кирилл Лукеренко [Електронний ресурс] / М. Бучельнікова. - Режим доступу: https://www.radiosvoboda.org/A/29317544.HTML

11. Росія рік поширювала фейки про Азовське море, готуючись до Керченської кризи (світова преса) [Електронний ресурс]. - Режим доступу: https://www.radiosvoboda. org/A/29650610.HTML

12. Писанська Н. Гібридне сміття і як його прибрати [Електронний ресурс] / Н. Писанська. - Режим доступу: https://www.radiosvoboda.org/a/germany-discussionfake-news/29490201.html

13. Рубан Т. «Євген Ланюк. Пост-правда, фейки та інформаційна війна» [Електронний ресурс] / Т. Рубан. - Режим доступу: https://varianty.lviv.ua/43429-yevhenlaniuk-post-pravda-feiky-ta-informatsiina-viina

14. Ладика I. «Фейки ближче, ніж ми думаємо»: розмова з Олександром Гороховським [Електронний ресурс] / I. Ладика. - Режим доступу: http://www.mediakrytyka.info/ onlayn-zhurnalistyka/feyky-blyzhche-nizh-my-dumayemo-rozmova-z-oleksandromhorokhovskym.html

15. Среміца В. Дезінформація і фейки такі ж згубні, як природні чи екологічні катастрофи - бельгійський експерт [Електронний ресурс] / В. Єреміца. - Режим доступу: https://www.radiosvoboda.org/A/29570796.HTML

16. Щур М. Російські боти стають активнішими з наближенням виборів - дослідження [Електронний ресурс] / М. Щур. - Режим доступу: https://www.radiosvoboda. org/A/29699806.HTML

17. Тимошенко Д. Украина опять «сбила «Боинг» - Минобороны России запуталось в версиях [Електронний ресурc] / Д. Тимошенко. - Режим доступу: https://www. radiosvoboda.org/a/donbass-realii/29502695.html 


\title{
THE UKRAINIAN EDITORIAL OFFICE OF RADIO LIBERTY: OPPOSITION TO RUSSIAN INFORMATION FAKES
}

\author{
Ivan Tsyperdiuk \\ Private institution of higher education «King Danylo University» \\ 35 Yevhena Konovaltsia, 76000, Ivano-Frankivsk, Ukraine \\ e-mail:ivandjuk@ukr.net \\ https://orcid.org/0000-0003-0940-5066
}

The article demonstrates the way the Ukrainian editorial office of Radio Liberty opposes to the spread of Russian information fakes. It was emphasized that while the Russian military aggression against Ukraine continues, of particular importance is the opposition of the media to the informational attacks that it accompanies, particularly by spreading fakes. It is shown that numerous fake messages invariably accompany any other provocation that Russia is preparing against Ukraine.

It was emphasized that during the Cold War one of the main tasks of the Ukrainian editorial office of Radio Liberty was to expose the disinformation that was massively produced by Soviet propaganda. The only way to effectively confront the state machine of disinformation was to spread the truth. And this work was successfully performed by it among a lot of other different radio stations broadcasting to the Soviet Union.

It is noted that the Ukrainian editorial office systematically works on informing the audience about the disclosure of the next fakes of Russian propaganda media and the spread of fakes by Russian trolls in social networks. The journalists of the editorial office, along with the colleagues from other Ukrainian media, activists from public initiatives are actively engaged in the detection of the next Russian information fakes.

The Ukrainian editorial office of Radio Liberty always places materials and interviews explaining what fakes are and how they are recognized and exposed.

In the media space there is a real war against the Russian information fakes at the moment and the Ukrainian editorial office of Radio Liberty, the activity of which is based on adherence to high journalistic standards, takes an active part in it on the side of professional and objective editorial offices. It, along with many other domestic media and public organizations, conducts an explanatory work on the danger posed by fakes.

By opposing to Russian fakes the Ukrainian editorial office of Radio Liberty is helping Ukraine withstand in the conditions of information warfare.

Key words: the Ukrainian editorial office of Radio Liberty, fakes, propaganda, information warfare. 